\title{
Clonazepam Use for Prevention of Acute and Delayed Vomiting Induced by Cisplatin-Based Chemotherapy for Lung Cancer
}

\author{
Masahiko Hayashi, ${ }^{*, a, c}$ Yusuke Takao, ${ }^{a}$ Chihiro Hata,${ }^{b}$ Hitomi Teramachi, ${ }^{c}$ and Teruo Tsuchiya ${ }^{c}$ \\ ${ }^{a}$ Department of Pharmacy, Ise General Municipal Hospital; ${ }^{b}$ Department of Internal Medicine, Ise General Municipal \\ Hospital; 3038 Kusube-cho, Ise, Mie 516-0014, Japan: and ${ }^{c}$ Laboratory of Clinical Pharmacy, Gifu Pharmaceutical \\ University; 1-25-4 Daigaku-nishi, Gifu 501-1196, Japan. \\ Received August 12, 2010; accepted August 31, 2010; published online September 2, 2010
}

\begin{abstract}
We investigated the efficacy of clonazepam as an antiemetic in cisplatin-based chemotherapy for lung cancer. Seven patients experienced cisplatin-induced vomiting despite antiemetic therapy including 5-hydroxytryptamine $_{3}\left(5-\mathrm{HT}_{3}\right)$ antagonist and dexamethasone. Therefore, the antiemetic therapy including clonazepam, 5-HT antagonist and dexamethasone was subsequently explored in the next course for the same seven patients. We administered clonazepam $(0.5$ or $1.0 \mathrm{mg} / \mathrm{kg})$ once a day orally for $5 \mathrm{~d}$ from day one prior to chemotherapy. The grade of delayed vomiting, evaluated according to Common Terminology Criteria for Adverse Events Version 3.0, in the courses of therapy with clonazepam was significantly lower than without clonazepam $(p=0.013)$. The patients whose serum clonazepam concentrations were below the lower limit of detection $(3.0 \mathrm{ng} / \mathrm{ml})$ experienced vomiting in three of three courses, whereas the patients whose serum clonazepam concentrations were higher than $4.3 \mathrm{ng} / \mathrm{ml}$ experienced no vomiting in six of seven courses. We observed that the symptom of cisplatininduced delayed vomiting is controlled with serum clonazepam levels in the order of $10.0 \mathrm{ng} / \mathrm{ml}$.
\end{abstract}

Key words antiemetic efficacy; clonazepam concentration; cisplatin-induced vomiting; lung cancer

Chemotherapy-induced nausea and vomiting (CINV) is a major problem for many patients and therefore it may affect the quality of life. ${ }^{1,2)}$ Chemotherapy-induced emesis is difficult to control completely because the emetic process is complex and many neuroreceptors are involved. Three distinct clinical forms of chemotherapy-induced emesis are acute, delayed and anticipatory. Cytotoxic agents are classified by emetogenic potential, to aid in selection of the appropriate antiemetic agents as having a high ( $>90 \%$ emetic risk), moderate, low or minimal potential for inducing emesis. The risk of emesis with cisplatin $\left(\geqq 50 \mathrm{mg} / \mathrm{m}^{2}\right)$ is high. ${ }^{3,4)}$ A combination of 5-hydroxytryptamine ${ }_{3}\left(5-\mathrm{HT}_{3}\right)$ antagonist plus dexamethasone (conventional antiemetic therapy) is recommended for the prevention of emesis after a high-dose cisplatin-based regimen. ${ }^{3,4)}$ But, conventional antiemetic therapy have been less effective in improving delayed nausea and vomiting than acute nausea and vomiting. ${ }^{5-7)}$ While pathophysiologic processes of delayed and acute emesis differ, some patients who achieve complete control of acute nausea and vomiting also experience severe delayed emesis. Anticipatory or conditioned emesis may occur in patients who have had poor control of either acute or delayed emesis with prior chemotherapy. A progressive increase in the numbers of patients with symptoms of anticipatory emesis per chemotherapy cycle was noted. ${ }^{89}$ Thus, elevated state anxiety has been linked to both a greater risk for developing, but also to a reduced efficacy of behavioral interventions for treating, anticipatory nausea and vomiting (ANV). ${ }^{10)}$ Benzodiazepines, most commonly lorazepam and diazepam, have been administered as antiemetics to prevent ANV. ${ }^{11,12)}$ There has been a case report on the use of clonazepam (a benzodiazepine) as an antiemetic. Koga et al. ${ }^{13)}$ reported that a patient suffered from refractory CINV despite extensive antiemetic therapy, but fully recovered after taking clonazepam. Hatae et al. ${ }^{14)}$ suggested that a four-drug combination of clonazepam, dexamethasone, metoclopramide and diphenhydramine prominently inhibited the cisplatin induced vomiting $(87.5 \%$ of courses). But, the concentration of clonazepam that appeared to have activity in controlling chemotherapy-induced vomiting is unknown.

We analyzed an association between the serum concentrations of clonazepam and activity in controlling cisplatininduced delayed vomiting in patients who experienced cisplatin-induced vomiting despite conventional antiemetic therapy.

\section{MATERIALS AND METHODS}

Patients The subjects were inpatients with lung cancer diagnosis, who experienced vomiting during the 5-d period after cisplatin-containing regimens despite conventional antiemetic therapy from February 2006 to July 2009 at Ise General Municipal Hospital. The same patients subsequently received clonazepam plus conventional antiemetic therapy in the next courses. Patients were excluded if there had been cisplatin or other cytotoxic agent dose reductions; a change for the worse of renal function; serum bilirubin more than $2.0 \mathrm{mg} / \mathrm{dl}$; serum aspartate aminotransferase more than 3 times the normal value; serum alanine aminotransferase more than 3 times the normal value; a performance status (PS) according to Eastern Cooperative Oncology Group (ECOG) scale of above $2^{15}$; the presence of uncontrolled brain metastases; seizure disorder; concurrent therapy with another benzodiazepines (unless given for night sedation) or antidepressants or antiepileptics; intake of St. John's wort; nausea or vomiting or the use of antiemetics in the $24 \mathrm{~h}$ before cisplatin chemotherapy; abdominal radiotherapy; and contraindications to clonazepam administration.

The study was performed in accordance with the Ethics Committee of our hospital according to the Helsinki Declaration of 1964 (revised in 2004). All patients gave informed consent.

Chemotherapy All patients were scheduled to receive cisplatin-based chemotherapy only on the first day (day 1) of 
treatment. Cisplatin was given as an intravenous infusion over a period of not more than $3 \mathrm{~h}$. All schedules were repeated every 3 or 4 weeks.

Antiemetic Treatment Approximately $60 \mathrm{~min}$ prior to the start of the cisplatin on day 1, all patients received prophylactics against acute emesis with granisetron $(3 \mathrm{mg})$ and dexamethasone $(12 \mathrm{mg})$ diluted in $100 \mathrm{ml}$ normal saline given as a slow intravenous injection over $60 \mathrm{~min}$. All patients received prophylactics against delayed emesis with dexamethasone ( $4 \mathrm{mg}$ ) diluted in $100 \mathrm{ml}$ normal saline given as a slow intravenous injection over $60 \mathrm{~min}$ from day 2 to day 4. Approximately $12 \mathrm{~h}$ prior to cisplatin patients began clonazepam $(0.5$ or $1.0 \mathrm{mg})$ orally on $1 \mathrm{~d}$ prior to chemotherapy (day -1$)$. Patients took clonazepam $(0.5$ or $1.0 \mathrm{mg})$ orally at 21:00 h on the day of chemotherapy (day 1) and continued for days $2-4$ following the next course of chemotherapy that occurred vomiting during the 5-d period after cisplatin-containing regimens despite conventional antiemetic therapy. Requirement of any other antiemetic treatment in spite of administering clonazepam was considered as an ineffective case of clonazepam therapy.

Response Assessment During the first $5 \mathrm{~d}$ (day 1-5), patients used a diary card to record the occurrence of vomiting episodes, any use of rescue therapy. Analysis of vomiting was performed separately for day 1 (acute episodes) and day $2-5$ (delayed episodes). All patients were asked to complete a daily diary on day $1-5$. These diary cards consisted of the number of vomiting episodes. Grade of vomiting was evaluated according to Common Terminology Criteria for Adverse Events Version 3.0. ${ }^{16)}$ Vomiting response (Nil) was defined as no vomiting and no rescue antiemetics in the overall $5-\mathrm{d}$ study period following the administration of clonazepam. Vomiting recorded is defined as over one episode of vomiting or administering rescue antiemetics in overall 5-d study period following the administration of clonazepam. Grade of vomiting in the acute phase was assessed by a graded scale of vomiting on day 1. Grade of vomiting in the delayed phase was recorded as the worst graded scale of vomiting experienced during day $2-5$.

Clonazepam Concentration Venous blood samples $(5.0 \mathrm{ml})$ were collected from arm vein at $18 \mathrm{~h}$ after the clonazepam administration on day 2. Samples were collected in blood collection tubes and centrifuged at $3000 \mathrm{rpm}$ at $25^{\circ} \mathrm{C}$ for $5 \mathrm{~min}$. After centrifugation, serum was separated and kept frozen at $-20{ }^{\circ} \mathrm{C}$ until assay. The serum concentrations of clonazepam were determined by HPLC. The measurement of serum clonazepam concentrations was performed at SRL, Inc. (Tokyo, Japan). The lower limit of detection of serum clonazepam level was $3.0 \mathrm{ng} / \mathrm{ml}$.

Statistical Methods Analysis of antiemetic efficacy in the acute/delayed phase was performed separately for the courses without or with clonazepam. Comparison between grade of vomiting in the courses of therapy with clonazepam and grade of vomiting in the courses of therapy without clonazepam in the acute/delayed phase was made using Chisquare for independence test. All tests were two-sided; $p<0.05$ was considered statistically significant.

\section{RESULTS}

Patient Characteristics Patient's information is summarized in Table 1. This analysis included seven patients (five men and two women). Mean( \pm S.D.) age was 59.4 \pm 10.3 years (range, 43-73 years). Median body surface area was $1.56 \pm 0.20 \mathrm{~m}^{2}$ (range, $1.35-1.87 \mathrm{~m}^{2}$ ). ECOG PS was 0 in six patients and 1 in one patient. All patients received $63.0 \pm 1.0$ $\mathrm{mg} / \mathrm{m}^{2}$ (range, $44.4-71.4 \mathrm{mg} / \mathrm{m}^{2}$ ) of cisplatin and other cytotoxic agents on the first day of chemotherapy (Table 2). This study included 17 courses of cancer chemotherapy (seven courses in absence of clonazepam and ten courses in

Table 1. Anthropometric Characteristics of Patients and Dose and Concentration of Clonazepam Vomiting Record from Day 1 to 5

\begin{tabular}{|c|c|c|c|c|c|c|c|c|c|c|c|c|c|}
\hline $\begin{array}{l}\text { Patient } \\
\text { number }\end{array}$ & Sex & $\begin{array}{c}\text { Age } \\
\text { (years) }\end{array}$ & $\begin{array}{c}\text { Weight } \\
(\mathrm{kg})\end{array}$ & $\begin{array}{l}\text { Height } \\
(\mathrm{cm})\end{array}$ & $\begin{array}{c}\text { Body } \\
\text { surface } \\
\text { area } \\
\left(\mathrm{m}^{2}\right)\end{array}$ & $\begin{array}{c}\text { ECOG } \\
\text { performance } \\
\text { status }\end{array}$ & Stage & Tissue & $\begin{array}{l}\text { Cancer } \\
\text { status }\end{array}$ & $\begin{array}{c}\text { Dose of } \\
\text { clonazepam } \\
(\mathrm{mg})\end{array}$ & $\begin{array}{c}\text { Dose of } \\
\text { clonazepam/ } \\
\text { weight } \\
(\mu \mathrm{g} / \mathrm{kg})\end{array}$ & $\begin{array}{c}\text { Serum } \\
\text { concentration } \\
\left.\text { of clonazepam }^{a}\right) \\
(\mathrm{ng} / \mathrm{ml})\end{array}$ & $\begin{array}{l}\text { Vomiting } \\
\text { record }^{b)}\end{array}$ \\
\hline 1 & Man & 73 & 39.4 & 165.0 & 1.35 & 1 & IV & Adenocarcinoma & Primary & 0.5 & 12.69 & 5.6 & Nil \\
\hline 2 & Man & 61 & 42.0 & 168.0 & 1.40 & 0 & IIIB & Unclear & Primary & 0.5 & 11.90 & 5.1 & Nil \\
\hline 3 & Man & 52 & 75.0 & 165.0 & 1.87 & 0 & IIIB & $\begin{array}{c}\text { Squamous } \\
\text { cell carcinoma }\end{array}$ & Primary & $\begin{array}{l}0.5 \\
1.0 \\
1.0\end{array}$ & $\begin{array}{r}6.67 \\
13.33 \\
13.33\end{array}$ & $\begin{array}{l}(-) \\
(-) \\
4.9\end{array}$ & $\begin{array}{c}\text { Recorded } \\
\text { Recorded } \\
\text { Nil }\end{array}$ \\
\hline 4 & Man & 70 & 58.0 & 167.5 & 1.65 & 0 & IVa & $\begin{array}{c}\text { Large cell } \\
\text { neuroendocrine } \\
\text { carcinoma }\end{array}$ & Primary & $\begin{array}{l}0.5 \\
1.0\end{array}$ & $\begin{array}{r}8.62 \\
17.24\end{array}$ & $(-)$ & $\begin{array}{l}\text { Recorded } \\
\text { Recorded }\end{array}$ \\
\hline 5 & Woman & 43 & 43.0 & 150.0 & 1.35 & 0 & IIIB & $\begin{array}{l}\text { Small cell } \\
\text { carcinoma }\end{array}$ & Primary & 1.0 & 23.26 & 8.1 & Nil \\
\hline 6 & Man & 56 & 63.0 & 167.0 & 1.72 & 0 & IB & $\begin{array}{l}\text { Squamous cell } \\
\text { carcinoma }\end{array}$ & Relapsed & 1.0 & 15.87 & 6.2 & Nil \\
\hline 7 & Woman & 61 & 53.0 & 160.0 & 1.55 & 0 & IIB & Unclear & Primary & 1.0 & 18.87 & 7.0 & Nil \\
\hline
\end{tabular}

a) In patient no. 3 and 4 where $(-)$ is indicated, the serum clonazepam levels remained below the limit of detection $(<3.0 \mathrm{ng} / \mathrm{ml})$. b) Nil (complete response) defined as zero instances of vomiting and no rescue antiemeticsin the overall 5-d study period following the administration of clonazepam. Recorded is defined as over one episode of vomiting or administering rescue antiemeticsin the overall 5-d study period following the administration of clonazepam. 
Table 2. Dose of Cisplatin and Other Combination Cytotoxic Agents

\begin{tabular}{|c|c|c|c|}
\hline \multirow{2}{*}{$\begin{array}{l}\text { Patient } \\
\text { number }\end{array}$} & \multirow{2}{*}{$\begin{array}{c}\text { Cisplatin } \\
\begin{array}{c}\text { Dose } \\
\mathrm{mg} / \mathrm{m}^{2}\end{array}\end{array}$} & \multicolumn{2}{|c|}{ Other combination cytotoxic agents used in treatment } \\
\hline & & & $\begin{array}{c}\text { Dose } \\
\mathrm{mg} / \mathrm{m}^{2}\end{array}$ \\
\hline 1 & 44.4 & Docetaxel & 55.6 \\
\hline 2 & 71.4 & Gemcitabine & 1000 \\
\hline 3 & 69.5 & Docetaxel & 56.1 \\
\hline 4 & 54.5 & Irinotecan & 54.5 \\
\hline 5 & 66.7 & Irinotecan & 56.3 \\
\hline 6 & 69.8 & Docetaxel & 55.2 \\
\hline 7 & 64.5 & Gemcitabine & 709.7 \\
\hline
\end{tabular}

Table 3. Frequency of Patients with Each Grade of Vomiting during the Acute Phase (Day 1) of Courses of Chemotherapy without/with Clonazepam

\begin{tabular}{cccc}
\hline \hline Grade $^{a)}$ & $\begin{array}{c}\text { Course of therapy } \\
\text { without clonazepam }\end{array}$ & $\begin{array}{c}\text { Course of therapy } \\
\text { with clonazepam }\end{array}$ & $p$ \\
\hline Grade 0 & 7 & 8 & 0.452 \\
Grade 1 & 0 & $1^{b)}$ & \\
Grade 2 & 0 & $1^{b)}$ &
\end{tabular}

Data were compared statistically between courses of therapy without clonazepam and courses of therapy with clonazepam in the acute phase (day 1) using the Chi-square for independence test. a) Grade of Common Terminology Criteria for Adverse Events Version 3.0. b) The same patient (patient no. 4) in the courses of therapy with clonazepam experienced vomiting (grade 1 and 2 ) in the acute phase respectively.

presence of clonazepam).

Due to insufficient efficacy of clonazepam $(0.5 \mathrm{mg} / \mathrm{d})$ as an antiemetic therapy, we subsequently increased the clonazepam dose to $1.0 \mathrm{mg} / \mathrm{d}$ in the next course for two patients (patient no. 3, 4). The clonazepam dose of $1.0 \mathrm{mg} / \mathrm{d}(17.24$ $\mu \mathrm{g} / \mathrm{kg} / \mathrm{d}$ ) for patient no. 4 yielded a serum level of $4.3 \mathrm{ng} / \mathrm{ml}$. The same clonazepam dose of $1.0 \mathrm{mg} / \mathrm{d}$ of each course for patient no. 3 yielded varying levels $(<3.0,4.9 \mathrm{ng} / \mathrm{ml})$. This patient experienced vomiting (grade 2 ) at day 2 of the initial clonazepam $(1.0 \mathrm{mg} / \mathrm{d})$ course.

Efficacy. The Assessment of Acute Emesis Table 3 shows grade of vomiting in the absence of clonazepam courses and the presence of clonazepam courses at the acute phase. A higher percentage of complete response in the control of vomiting was observed on day 1 in both courses, though the differences were not statistically significant ( $p=0.452$, Chi-square for independence test). But, all patients in the absence of clonazepam courses in the acute phase failed to experience vomiting and did not require rescue. One patient (patient no. 4) in the presence of clonazepam courses experienced vomiting (grade 1 and 2 ) in the acute phase respectively.

The Assessment of Delayed Emesis Comparison between grade of vomiting in the courses of therapy with clonazepam and grade of vomiting in the courses of therapy without clonazepam in delayed phase showed that the grade of vomiting in the courses of therapy with clonazepam was significantly lower than without clonazepam ( $p=0.013$, Chisquare for independence test) (Table 4).

The Assessment of Efficacy of Clonazepam in Preventing Emesis and the Clonazepam Concentration We investigated the relationship between efficacy of clonazepam in preventing chemotherapy-induced vomiting and the serum concentrations of clonazepam. Patients whose serum clonazepam concentrations were below limit of detection $(3.0$
Table 4. Frequency of Patients with Each Grade of Vomiting during the Delayed Phase (Day 2-5) of Courses of Chemotherapy without/with Clonazepam

\begin{tabular}{cccc}
\hline \hline Grade $^{a)}$ & $\begin{array}{c}\text { Course of therapy } \\
\text { without clonazepam }\end{array}$ & $\begin{array}{c}\text { Course of therapy } \\
\text { with clonazepam }\end{array}$ & $p$ \\
\hline Grade 0 & 0 & 6 & 0.013 \\
Grade 1 & 3 & 0 & \\
Grade 2 & 4 & 4 & \\
\hline
\end{tabular}

Data were compared statistically between courses of therapy without clonazepam and courses of therapy with clonazepam in the delayed phase (day 2-5) using the Chisquare for independence test. a) Grade of Common Terminology Criteria for Adverse Events Version 3.0.

$\mathrm{ng} / \mathrm{ml}$ ) experienced vomiting in three of three courses; but the patients whose serum clonazepam concentrations were more than $4.3 \mathrm{ng} / \mathrm{ml}$ experienced no vomiting in six of seven courses (Table 1).

\section{DISCUSSION}

Emesis, measured by counting the number of vomiting episodes after cancer chemotherapy, is a most important clinical trial end point for studies of antiemetic drugs. Studies have documented ${ }^{3)}$ that the occurrence of complete response (no vomiting episodes and no rescue medications administered after cancer chemotherapy) is a highly accurate and reliable measure. The number of vomiting episodes after cancer chemotherapy was performed to evaluate efficacy of clonazepam as an antiemetic agent. During the first $5 \mathrm{~d}$ (day $1-5$ ), patients used a diary card to record the occurrence of vomiting episodes. In these diary cards, all patients recorded their prevailing condition.

Koga $e t$ al. ${ }^{13)}$ reported that a patient suffered from refractory doxorubicin and docetaxel combination chemotherapy induced vomiting despite extensive antiemetic therapy, but fully recovered after taking clonazepam. In our study, all subjects experienced cisplatin-induced vomiting despite conventional antiemetic therapy. While the risk of emesis with doxorubicin and docetaxel is moderate, the risk of emesis with cisplatin is high. Similar to other reports, ${ }^{5,6)}$ a higher percentage of complete response in the control of vomiting was observed in this study on day 1 both in the absence of clonazepam courses and in the presence of clonazepam courses. But, all patients in the absence of clonazepam courses in the acute phase failed to experience vomiting and did not require rescue. One patient (patient no. 4) in the presence of clonazepam courses experienced vomiting (grade 1 and 2) in the acute phase respectively. Anticipatory emesis may occur in patients who have had poor control of emesis with prior chemotherapy. A previous episode of poorly controlled emesis during an absence of clonazepam course has been linked to a greater risk for developing anticipatory vomiting.

Clonazepam's action is mediated by gamma-aminobutyric acid (GABA) receptor interactions. Clonazepam is known to have not only anxiolytic, sedative and muscle relaxant effects but also an anticonvulsant effect. ${ }^{17,18)}$ Clonazepam showed efficacy in preventing chemotherapy-induced vomiting, thereby reducing patient's anxiety, preventing the symptom of diaphragmatic and gastrointestinal myoclonus. ${ }^{13)}$ Myoclonic epilepsy was controlled with clonazepam levels of $20 \mathrm{ng} / \mathrm{ml} .{ }^{17)}$ 
The relationship between efficacy of clonazepam in preventing chemotherapy-induced vomiting and serum concentration of clonazepam should be evaluated by using the lower clonazepam levels. But, venous blood samples were collected at 15:00 h for reason due to work related convenience sampling.

The same clonazepam dose of $1.0 \mathrm{mg} / \mathrm{d}$ of each course for patient no. 3 yielded varied levels $(<3.0,4.9 \mathrm{ng} / \mathrm{ml})$. This patient experienced vomiting (grade 2) at day 2 of the initial clonazepam $(1 \mathrm{mg} / \mathrm{d})$ course. He did not vomit in the night of day 1 . The low clonazepam concentration $(<3.0 \mathrm{ng} / \mathrm{ml})$ of day 2 (15:00) was not caused by his poor oral bioavailability induced by vomiting of day 2 . When we administered the same dose $(1.0 \mathrm{mg} / \mathrm{d})$ for each course, a difference was found between the first and second sample in clonazepam levels. But, the reasons for this difference of clonazepam levels is unclear.

The clonazepam dose of $1.0 \mathrm{mg} / \mathrm{d}(17.24 \mu \mathrm{g} / \mathrm{kg} / \mathrm{d})$ for patient no. 4 yielded a serum level of $4.3 \mathrm{ng} / \mathrm{ml}$. His clonazepam concentration per dose ratio was lower than those of other patients. Due to the insufficient efficacy of clonazepam $(1.0 \mathrm{mg} / \mathrm{kg})$ as an antiemetic therapy, we inferred that increase of clonazepam dose is necessary for the control of vomiting for this patient.

Gender-related differences in diazepam pharmacokinetics were noted. Women had higher concentration levels for diazepam than men. ${ }^{19)}$ When the patients in this study were split according to gender (five men and two women), differences of ratios of levels $(\mathrm{ng} / \mathrm{ml})$ to oral doses $(\mu \mathrm{g} / \mathrm{kg})$ were insignificant.

Findings show there is little correlation between oral doses and the drug levels. The range of effective clonazepam concentrations is wide. ${ }^{15,20)}$ We observed that the symptom of refractory cisplatin-induced delayed vomiting is controlled with clonazepam levels in the order of $10.0 \mathrm{ng} / \mathrm{ml}$ that would be lower than the level of clonazepam $(20.0 \mathrm{ng} / \mathrm{ml})$ that have been shown to control myoclonic epilepsy. Several studies ${ }^{13,14)}$ have indicated the efficacy of clonazepam on CINV. In this study with small number $(n=7)$ of patients we could define the first association between efficacy of clonazepam in preventing chemotherapy-induced vomiting and the serum concentrations of clonazepam. Further cross-sectional studies are needed to determine the relationship between clonazepam concentrations and the clinical outcome as an antiemetic therapy.

In conclusion, we report the efficacy of clonazepam in pre- venting chemotherapy-induced vomiting and the serum concentrations of clonazepam in lung cancer patients. We observed that the symptom of refractory cisplatin-induced delayed vomiting is controlled with clonazepam levels in the order of $10.0 \mathrm{ng} / \mathrm{ml}$.

\section{REFERENCES}

1) Bloechl-Daum B., Deuson R. R., Mavros P., Hansen M., Herrstedt J., J. Clin. Oncol., 24, 4472-4478(2006)

2) Morita S., Kobayashi K., Eguchi K., Matsumoto T., Shibuya M., Yamaji Y., Sakamoto J., Ohashi Y., Jpn. J. Clin. Oncol., 33, 470-476 (2003).

3) Kris M. G., Hesketh P. J., Somerfield M. R., Feyer P., Clark-Snow R., Koeller J. M., Morrow G. R., Chinnery L. W., Chesney M. J., Gralla R. J., Grunberg S. M., J. Clin. Oncol., 24, 2932-2947 (2006).

4) Gralla R. J., Osoba D., Kris M. G., Kirkbride P., Hesketh P. J., Chinnery L. W., Clark-Snow R., Gill D. P., Groshen S., Grunberg S., Koeller J. M., Morrow G. R., Perez E. A., Silber J. H., Pfister D. G., J. Clin. Oncol., 17, 2971-2994 (1999).

5) Hesketh P. J., Kris M. G., Grunberg S. M., Beck T., Hainsworth J. D., Harker G., Aapro M. S., Gandara D., Lindley C. M., J. Clin. Oncol., 15, 103-109 (1997).

6) Latreille J., Pater J., Johnston D., Laberge F., Stewart D., Rusthoven J., Hoskins P., Dhaliwal H., Warr D., Shepherd F., Mee D., Nishimura L., Osoba D., Zee B., J. Clin. Oncol., 16, 1174-1178 (1998).

7) Olver I., Paska W., Depierre A., Seitz J. F., Stewart D. J., Goedhals L., McQuade B., McRae J., Wilkinson J. R., Annals Oncology, 7, 945952 (1996).

8) Markman M., Cleve. Clin. J. Med., 69, 609-617 (2002).

9) Aapro M. S., Kirchner V., Terrey J. P., Br. J. Cancer, 69, 957-960 (1994).

10) Andrykowski M. A., Psychosom. Med., 52, $458-475$ (1990).

11) Laszlo J., Clark R. A., Hanson D. C., Tyson L., Crumpler L., Gralla R., J. Clin. Oncol., 3, 864-869 (1985).

12) Robins H. I., Ershler W. B., De Jongh L., Chang Y. C., Drozdowicz P. M., Carr B. I., Meyer D. K., Med. Pediatr. Oncol., 7, 247-249 (1979).

13) Koga M., Nakadozono M., Nukariya K., Nogi H., Kobayashi T., Nakayama K., Anticancer Res., 28, 2433-2436 (2008).

14) Hatae M., Nakamura Y., Mitsuo M., Sakurai K., Asano H., Onishi Y., Hokanishi H., Gan to Kagaku Ryoho, 17, 1495-1499 (1990).

15) Oken M. M., Creech R. H., Tormey D. C., Horton J., Davis T. E., McFadden E. T., Carbone P. P., Am. J. Clin. Oncol., 5, 649-655 (1982).

16) Trotti A., Colevas A. D., Setser A., Rusch V., Jaques D., Budach V., Langer C., Murphy B., Cumberlin R., Coleman C. N., Rubin P., Semin. Radiat. Oncol., 13, 176-181 (2003).

17) Khouzam H. R., Highet V. S., The Neurologist, 3, 120-126 (1997)

18) Nardi A. E., Perna G., Int. Clin. Psychopharmacol., 21, 131-142 (2006).

19) Macleod S. M., Giles H. G., Bengert B., Liu F. F., Sellers E. M., J. Clin. Pharmacol., 19, 15-19 (1979).

20) Baruzzi A., Bordo B., Bossi L., Castelli D., Gerna M., Tognoni G., Zagnoni P., Int. J. Clin. Pharmacol. Biopharm., 15, 403-408 (1977). 